\title{
Historical records of volcanic eruptions deserve more attention
}

David M. Pyle ${ }^{\dagger 1}$ and Jenni Barclay ${ }^{2}$

${ }^{1}$ Department of Earth Sciences, University of Oxford, Oxford, UK.

${ }^{2}$ School of Environmental Sciences, University of East Anglia, Norwich, UK.

${ }^{\dagger}$ David Pyle, david.pyle@earth.ox.ac.uk

To reduce the risks and uncertainty that surrounds volcanic eruptions, attention must be given to all available data. Historical records can provide insight into past eruptions, as well as the social and political responses to volcanic activity.

Most volcanoes spend much of their life in a state of repose, with non-eruptive episodes lasting for decades to centuries. In contrast, volcanic eruptions are typically over in weeks to months.

Technological innovations mean that volcanologists can now capture gas, deformation, and seismic data from the fleeting moments of eruption. However, the focus on activity, rather than inactivity, could result in crucial information being overlooked. Indeed, the ability to mitigate volcanic risk is limited by a lack of understanding of the transitions from repose to unrest, and unrest to eruption such that the 'next big eruption' is likely to happen at a volcano for which there is no prior instrumental record of activity. Without exploring the historical records, it is therefore not possible to know in advance what eruption precursors there may be.

\section{[H1] Limitations of volcano monitoring}

Geologists are practiced in teasing apart the rock records of past volcanic eruptions. Petrological and geochemical analysis of volcanic deposits and their constituent materials can be used to unravel the eruption dynamics and the physical and chemical processes that precede eruption. Unsurprisingly, the forensic geological approach that is used to study past eruptions has typically focussed on the largest and rarest events: landscape-modifying eruptions of the past millennia that literally shaped the volcanoes we know today. However, the geological records formed by small, but frequent, eruptions that affect local populations are often poorly studied owing to the transient nature of their deposits.

Quantitative analysis of earthquakes and other phenomena (such as gas emissions and ground deformation) has also been an established part of the volcanologists' toolkit for many decades. However, monitoring the world's 1500 potentially-active volcanoes is difficult, and many potentiallyactive volcanoes lack permanent ground-based monitoring ${ }^{1}$. Even though we are now in an era of 
global satellite surveillance, these challenges remain. For example, a quarter of the volcanoes that have experienced major explosive eruptions since the start of the satellite era in 1979 had no prior activity during the previous century (Fig 1). As a result, the volcanoes that are likely to yield the most destructive eruptions of the next decade might lack prior instrumental records of the transitions from repose to unrest to eruption. Therefore, for people and authorities that manage volcanic crises, historical records of these transitions are vital ${ }^{2}$.

\section{[H1] Historical Records of Volcanic Eruptions}

Historical records, which may include eyewitness accounts in letters and newspapers, or official correspondence and government documents, contain multiple strands of data that offer insight into the repose-unrest-eruption cycle at potentially dangerous volcanoes in the absence of instrumental records. However, although historical records are used to inform hazard models for other natural phenomena (such as earthquakes ${ }^{3}$ ), this data is rarely considered in studies of active volcanic systems. Like all data, historical accounts need close scrutiny and careful analysis. Nevertheless, their rich potential will enhance our capacity to prepare for and respond to future hazard events.

For example, Spanish colonial archives ${ }^{4}$ provide exquisite details of the events that occurred in the three months after a violent eruption of Fuego volcano, Guatemala, in August 1717. The archives track an intrusion of magma, which caused a sequence of large earthquakes that triggered destructive mudflows from the nearby Agua volcano. The sequencing of events, and their consequences for people living nearby, could not have been deduced from geological evidence alone. Likewise, data collected in the immediate aftermath of the great eruption of Krakatoa in 1883, which ranges from tide gauge and barograph measurements to ships logs documenting distant encounters with ash and floating rafts of pumice, provide unrivalled insights into the local and global impacts of the destruction of a volcanic island.

Historical records that document the personal experiences of those affected by past activity, as well as those who managed the crisis or the response, can inform on the magmatic processes that precede eruption and offer new insights into the human dimensions of disaster. For example, $\mathrm{S}$. Keane $e^{5}$ captured, in a contemporary poem, the rapid reawakening of the Soufrière of St Vincent in April 1979, a volcano that had been quiet for 70 years apart from a small extrusion of lava in 1971. In the early hours of April $13^{\text {th }}$, after a short but unfelt swarm of small earthquakes, percussive explosions marked the start of the eruption:

'That thing split Good Friday in two / and that good new morning groaned / and snapped' 
Thus, historical records, in this case in the form of a poem, can provide information about the transition from repose to eruption at a potentially dangerous volcanic centre. The explosive phase of the 1979 eruption of the Soufrière lasted for two weeks, causing widespread damage to that year's banana crops, but no loss of life. However, had the population of St Vincent not triggered an immediate self-evacuation ${ }^{2}$ following the first audible signs of the eruption, the number of human casualties could have been high. Keane's poem records this evacuation and, therefore, demonstrates how the stories and memories of past eruptions can help to mitigate volcanic hazards.

'within minutes / people / who had always been leaving nowhere / began arriving nowhere / entire lives stuffed in pillow cases'.

On St Vincent, memories of past volcanic events run deep. A violent eruption in May 1902 killed 1600 people, and stories of the sights and sounds that marked the start of the eruption are well known among Vincentians ${ }^{6}$. The stories of this prior eruption, and of the events that led up to it, meant that the instinctive response of the St Vincent population to the first sounds of volcanic activity was to evacuate.

The decision-making processes that conditioned the official responses to the eruptions of St Vincent are minutely documented in colonial government papers that preserve a blow-by-blow narrative account of the events. Government documents represent an important resource for constraining the sequences of events, and their impacts, at restless volcanic systems worldwide. Telegrams and notes of meetings reveal the difficulties of grappling with incomplete information in a rapidly-changing environment, and the internal conflicts that arise in any emergency.

Historical records of eruptions exist for many volcanoes worldwide that lie near centres of population. Studying historical records will deepen understanding of eruption processes and impacts, and improve confidence around decision-making in advance of and during future eruptive or non-eruptive crises. In an era when global satellite monitoring of volcanoes is opening new avenues in detecting change at restless volcanoes, historical records provide a rich and complementary perspective for understanding the consequences of volcanic unrest, and chronicle the trajectories of volcanic risk, past, present and future.

\section{References.}

1 - Loughlin, S., Sparks, S., Brown, S., Jenkins, S. \& Vye-Brown, C. Global Volcanic Hazards and Risk. (Cambridge University Press, Cambridge, 2015). 
2 - Barclay, J. et al. Livelihoods, wellbeing and the risk to life during volcanic eruptions. Frontiers Earth Sci 7, 205 (2019).

3 - Ambraseys, N.N. \& Melville, C.P. A history of Persian earthquakes. (Cambridge University Press, Cambridge, 2005).

4 - Hutchison, A. A., Cashman, K. V., Williams, C. A. \& Rust, A.C. The 1717 eruption of Volcán de Fuego, Guatemala: Cascading hazards and societal response. Quat. Int. 394., 69-78 (2016)

5 - Keane, S. The Volcano Suite (Reliance Press, St Vincent, 1979).

6 - Pyle, D. M., Barclay, J. \& Armijos, M.T. The 1902-3 eruptions of the Soufrière, St Vincent: Impacts, relief and response. J. Volcanol. Geotherm. Res. 356, 183-199 (2018).

7 - Global Volcanism Program, Volcanoes of the World, v. 4.8.5. (Smithsonian Institution, Washington, 2013). Downloaded 03 Feb 2020. https://doi.org/10.5479/si.GVP.VOTW4-2013 


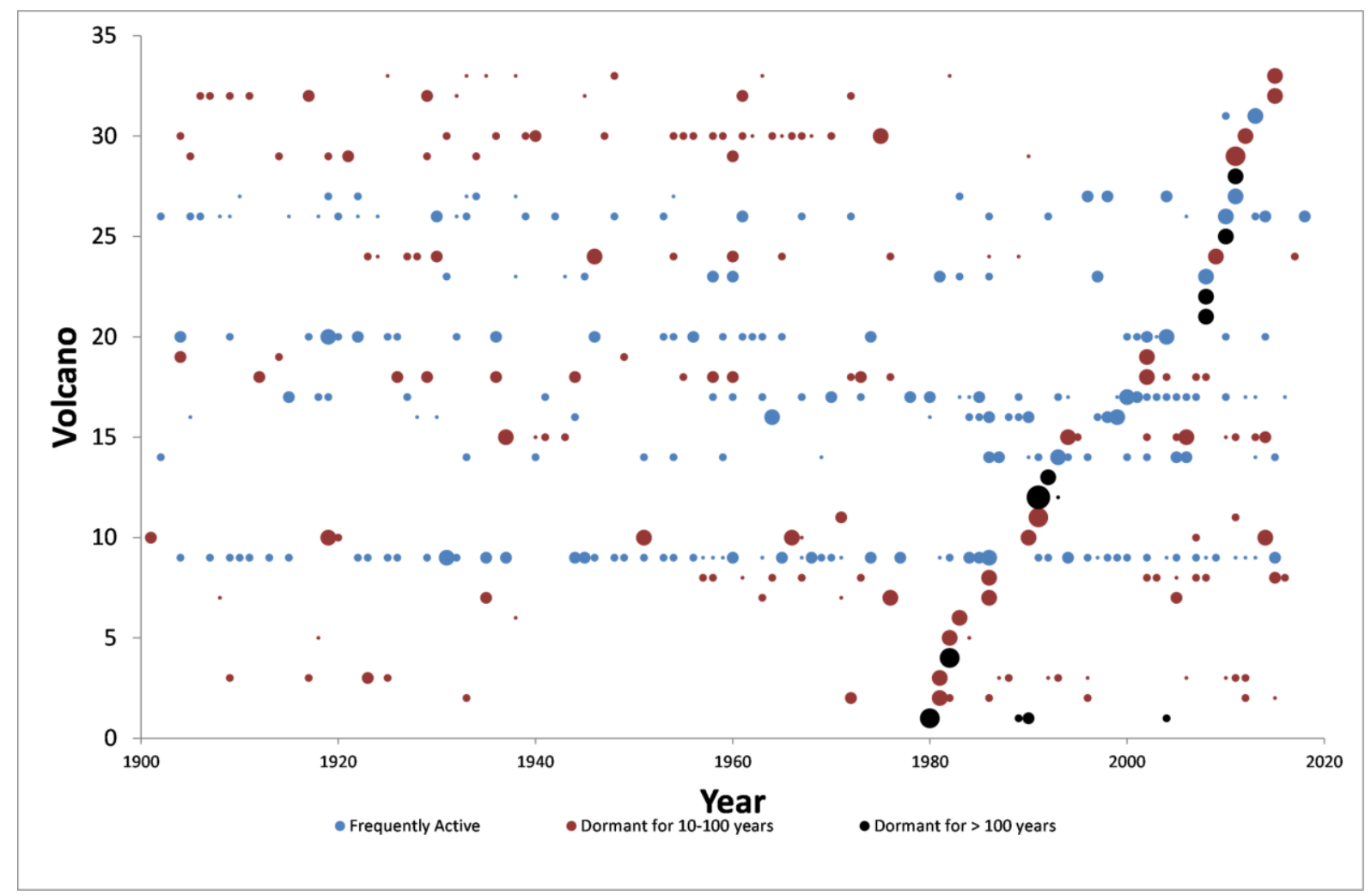

Caption.

Figure 1.

Summary of the volcanic activity at 33 active volcanoes during the satellite era. Activity at 33 volcanoes that are known to have experienced at least 1 eruption with a Volcanic Explosivity Index of 4 or larger since the start of the 'satellite era' in 1979.Coloured symbols show dates of all known eruptions since $1900 \mathrm{AD}$. Volcanoes include those with no record of activity in the $20^{\text {th }}$ century (black); volcanoes in repose for at least a decade prior to the major eruption (red); and volcanoes showing frequent or recent activity (blue). Data source - Smithsonian Institution, Global Volcanism Program ${ }^{7}$.

List of volcanoes: 1 - St Helens; 2 - Alaid; 3 - Pagan ; 4 - El Chichón; 5 - Galunggung; 6 - Colo; 7 Augustine; 8 - Chikurachi; 9 - Klyuchevskoy; 10 - Kelut; 11 - Cerro Hudson; 12 - Pinatubo; 13- Spurr; 14 - Lascar; 15 - Rabaul; 16 - Sheveluch; 17 - Ulawun; 18 - Reventador; 19 - Ruang; 20 - Manam; 21 - Chaitén; 22 - Kasatochi; 23 - Okmok; 24 - Sarychev Peak; 25 - Eyjafjallajökull; 26 - Merapi; 27 Grimsvotn; 28 - Nabro; 29 - Puyehue-Cordon Caulle; 30 - Tolbachik; 31 - Sinabung; 32 - Calbuco; 33 - Wolf. 